\title{
Implementation of Sort Card Method to Improve Motivation and Learning Outcomes of MAN Batu Students
}

\author{
Rasmuin \\ Universitas Islam Negeri Maulana Malik Ibrahim Malang \\ Email: muin@uin-malang.ac.id
}

\begin{abstract}
This classroom action research uses the Kemmis and Mc Taggart model to determine the effect of the sort card method in learning History of Islamic Culture. The subjects of this study were 34 students of grade XI IPS 2 MAN Batu, East Java. The instruments in this study include observation, documentation, interviews and tests. The collected data were analyzed using descriptive analysis techniques. The results showed that the sort card method was able to increase student learning motivation. It is evident from the increasing active participation in the learning process. This method is also able to improve student learning outcomes. It is evident from the increasing of learning outcomes in cycle 1 and 2. At the time of the pre-cycle, the highest score obtained by students was 80 with a passing percentage of $23 \%$. This score increased in first cycle with the highest score of 90 with a percentage of completeness of $71 \%$. In the second cycle student learning outcomes have increased again. The highest score was recorded at 98 with the percentage of completeness increased to $88 \%$.
\end{abstract}

Keywords: History of Islamic Culture, Learning Motivation, Learning Outcomes, Sort Card Method

Abstrak
Penelitian ini bertujuan untuk mengetahui pengaruh
penggunaan metode sort card dalam pembelajaran Sejarah
Kebudayaan Islam. Jenis penelitian yang digunakan adalah
penelitian Tindakan kelas menggunakan model Kemmis and
MC Taggart. Subyek penelitian ini adalah 34 siswa kelas XI IPS
2 MAN Batu Jawa Timur. Instrumen dalam penelitian ini
meliputi observasi, dokumentasi, wawancara dan tes. Data
yang terkumpul dianalisis dengan menggunakan Teknik
analisis deskriptif. Hasil penelitian menunjukkan bahwa
metode sort card mampu meningkatkan motivasi belajar siswa.
Hal ini terlihat dari meningkatnya partisipasi aktif siswa dalam


proses pembelajaran. Metode ini juga mampu meningkatkan hasi belajar siswa. Peningkatan ini bisa diketahui dari adanya peningkatan hasil belajar pada siklus 1 dan 2. Pada saat pra siklus tercatat nilai tertinggi yang diperoleh siswa sebesar 80 dengan perentase kelulusan sebanyak $23 \%$. Nilai ini meningkat pada siklus 1 dengan nilai tertinggi 90 dengan persentase ketuntasan sebesar $71 \%$. Pada siklus 2 hasil belajar siswa kembali mengalami peningkatan. Nilai tertinggi tercatat sebesar 98 dengan persentase ketuntasan naik menjadi $88 \%$.

Kata Kunci: Sejarah Kebudayaan Islam, Motivasi Belajar, Hasil Belajar, Metode Sort Card

\section{INTRODUCTION}

The existence of madrasas as Islamic educational institutions in Indonesia, according to Islamic education experts, is not a historical link in the growth and development of madrassas in classical Islamic times. But madrasas in Indonesia emerged as a logical continuation of previous Islamic education institutions, especially Java, namely pesantren. Madrasa, as a school under the Ministry of Religion, provides more religious education compared to other public schools at the same level. It has caused many parents to send their children to madrasas to introduce their children to religion. One of the religious lessons given at the madrasa is the History of Islamic Culture. This subject studies about the history of Islam both in the early to the present spreading. Many studies have been done to prove the effectiveness of sort card for learning, however, the difference of this study to another is stated the novelty of this study, it is tried to prove that sort card also being useful for studying History of Islamic Culture in Islamic school.

History of Islamic Culture Subjects can be ensured in every Islamic educational institution. These subjects have significant benefits for the lives of Muslims (Lahmar, 2020, p. 409; Manshur, 2020, p. 114). By studying the history of Islam, a person will be able to understand the instructions contained in the Qur'an and Sunnah and to develop pride in a Muslim. Studying history will also bring each individual to understand the current situation and design future lives with careful calculation (Al Harafi, 2016). For Muslims, history and historical knowledge in Islam are essential and have significant benefits in the study of Islam (Saif, 2020). Muslims can adhere to any account learned from the time of the Prophet Muhammad, Khulafaur Rashidin, great scholars, and other Islamic 
leaders (Zuhairini, 1986).

In the process of learning History of Islamic Culture in this madrasa, it does not escape the various kinds of problems that occur (Mashudi, 2020). These problems include students feeling bored, ignoring the teacher in front of the class, doing activities outside the topic of learning, sleeping while learning, scribbling on paper, disturbing other friends, playing mobile phones, often permission to go out to the bathroom and so forth (Fauziyah, 2013). It requires the teachers to immediately find solutions to the problems that occur so that the learning process can run well, and the learning objectives can be accomplished.

The same thing happened in MAN Batu City, East Java. In general, students consider that the lessons in Islamic Cultural History are very dull and challenging to learn. It is because, in the course of the History of Islamic Culture, students must be able to memorize years, names, and many other significant events in Islam. Students also do not like this lesson and are less interested in learning it because it is less impressive, tedious, and complicated. Therefore, teachers, especially the History of Islamic Culture teachers must find ways to improve student motivation.

From these various problems, the researcher realizes that there is something wrong with the learning process that occurs in the classroom. One such mistake is the lack of variation in both the methods and models used by teachers in learning. The use of conventional learning methods will cause students to experience boredom in participating in teaching and learning activities. As a result, student motivation to learn is low. Maslow, as quoted by Hamalik, stated that successful motivation must come from meeting the basic needs of the students themselves. These needs include physiological needs, safety and security, acceptance and love, self-esteem and self-realization (Hamalik, 2007). Many media can be used by teachers in the form of audio, visual, and audiovisual. The media must also be supported by appropriate learning models so that teaching and learning activities are optimal. The result is that learning objectives can be achieved.

From some preliminary studies, it was found that the sort card method was able to increase student motivation and learning outcomes. First, qualitative research conducted by Fakhrurazi revealed that this method was able to improve student motivation and learning outcomes in the Qur'an and Hadith subjects (Fakhrurrazi, 2016). Second, Uswatun and Siti's research showed an increase in 


\section{Fitrah}

$\triangle$ Jurnal Kajian Ilmu-ilmu Keislaman

Vol. 6 No. 2 December 2020

cognitive, affective, and psychomotor domains after using the sort card learning method (Hasanah \& Wahyuni, 2019). Third, a study conducted by Sita et al. also got the same conclusion, namely, the sort card method can improve student learning outcomes (Husnul et al., 2018). Halimatus and Yuli obtained the same positive results in their research conducted in Class V of the Kebonsari cluster, Sukun District, Malang City (Sakdiyah \& Sari, 2016).

Sort card method is a method of learning in the form of pieces of paper formed on cards or pieces of paper that contain information or learning material (Giraudeau et al., 2019; Petrie et al., 2011). This method is an active learning method to teach concepts, characteristics, facts about objects, or review knowledge that has been delivered previously(Mahmud \& Idham, 2017). This method relies on dominant physical movements so that it can help condition the class to be more dynamic than the previous condition. Namely, conditions that are considered boring that can cause boredom in students(Hartono, 2008).

In short, the steps in learning are as follows:

1. The teacher gives a card to each student that contains information about one or more categories.

2. Students are asked to look for friends who have cards that contain information in the same category.

3. Ask students to present each card they bring to their classmates.

4. While listening to the presentation, the other students are instructed to note essential points in each category.

The purpose of this method is to express the memory of the subject matter that students have learned. This method is also used as a tool to review the material that has been obtained by students. From here, it can be seen whether students have understood and remembered the material that has been given or not (Suparlan, 2006). Things that must be considered in this method include students who have studied cards that are not given a serial number, made with the same size, without a specific code on each card, the number of cards adjusted to the number of students, and the material.

In applying this sort card method, a teacher should refer to the thinking of Syed Naquib Al Athas on the multi-approach in the Islamic education process. He advised teachers to stick to the tawhid method which prioritizes human nature as religious beings. If this can be applied, the goals of education will be integrally realized because there is a balance between the understanding and 
appreciation of students( $\mathrm{Al}$ Attas, 1979). If it is realized, the knowledge gained by students will not be misused because students will always feel close to Allah(Rahman, 1984).

Based on some of the above, to increase the weakness of student motivation and learning outcomes in the subjects of Islamic Cultural History in class XI IPS 2 MAN Batu City, researchers conducted classroom action research using Sort Card learning methods. This method is used to teach concepts, characteristics, classifications, facts about things, make students active in learning, and not feel bored(Zaini, 2008). This method is also useful in training speaking skills and teamwork. Besides, this method is also able to improve the memory of learning material that students have learned(Hartono, 2008). This research was conducted on the content of the phases of the Umayyad dynasty and its caliphs.

\section{RESEARCH METHODS}

This research is a classroom action research study that is focused on improving student learning processes and outcomes (Mulyasa, 2011). Carr and Kemmis, as quoted by Suyadi, said that classroom action research is a reflection conducted by teachers, students, or principals in certain situations aimed at improving all aspects of learning (Suyadi, 2011). This research was well designed by the teacher, carried out, and reflected collaboratively and participative so that it could be carried out optimally (Arikunto, 2006). This research was conducted in January 2020 in MAN Batu City, East Java, with 34 students as the subjects of class XI IPS 2. Data obtained through observation techniques, documentation, interviews, and tests conducted in each cycle. The data collected were analyzed using descriptive analysis techniques. The data that has been collected is reduced (data reduction), presented (data display), then conclusions are drawn from the data. This analysis was carried out in depth to determine changes in motivation and student learning outcomes during the History of Islamic Culture learning.

\section{RESULTS AND DISCUSSION Pre-Cycle Analysis}

In this pre-cycle, the researchers used conventional methods in the learning process. Class situations and conditions are not very conducive. Many students do not pay attention to the material delivered by the teacher. They are mostly busy with their activities, and there seems to be no motivation for learning. Based 
Vol. 6 No. 2 December 2020

on the test results at the time of this pre-cycle, the learning outcomes obtained by XI IPS 2 MAN students in Batu City are still deficient. Post-test scores conducted on 34 students in class XI IPS 2 get an average value of 65 . The percentage of students' mastery learning reached only $23 \%$. The results of this post-test are used as evaluation material to improve the learning activities that will be carried out in the first cycle.

From the evaluation of the learning process carried out in the pre-cycle, several things have been identified as material for improvement for cycle 1 , among others:

1. Classroom learning activities are still focused on the teacher

2. Material delivered using the lecture method

3. Students have not been too actively involved in learning

4. The learning process without using learning media

The problems identified were used by researchers as a reference to improve the learning process that was designed in the first cycle. In the first cycle, the researcher tried to apply learning by using the sort card method to achieve better results.

\section{Cycle Analysis 1}

In the next process, the researcher used the sort card method to carry out learning in the classroom. This method emphasizes the role of students in the learning process. This process seeks to improve the learning patterns that previously occurred in the pre-cycle. There are several things done in the first cycle, among others:

1. Learning is centered on students.

2. Teachers are more facilitators and explain the material that learners do not understand.

3. The teacher prepares the cards that have been made

4. Students form groups and discuss

5. Each group is given a card (statement) and identify the report according to its part (false or true)

6. Each group presents identification cards in the existing classification.

The learning process in the first cycle has begun to have positive changes. Students begin to be more motivated and active to participate in learning. After 
the process of learning activities, tests are held to find out the learning outcomes of students in this cycle. Recorded an average value of 76 with a percentage of completeness reached $71 \%$, the highest score of 90 , and the lowest 60 . Although there has been an increase in both motivation and student learning outcomes, the process of the first cycle is still experiencing some obstacles. These constraints include students who do not understand the learning path that has been explained by the teacher, there are still those who do not pay attention, and some of them are still embarrassed in issuing opinions during the discussion. It needs to be refined again, so further action is required for the second cycle.

\section{Cycle Analysis 2}

In this second cycle, the researchers focus on perfecting the deficiencies that occur in the first cycle. The same method is used in this second cycle. The steps are also the same. However, before acting, the researcher tried to improve communication with students in explaining the stages of the learning process to be passed. Researchers also increase supervision and observation throughout the process.

From the second cycle that has been carried out, the results obtained are quite satisfying. Motivation and student learning outcomes have increased significantly. Recorded the highest value achieved by students reached 98 with the lowest score of 70 . The average grade score is 84 , and the percentage of completeness is $88 \%$. Based on the above data, it can be concluded that the use of the sort card method in the material Phases of the Umayyad Dynasty, along with its Khalifah in the subjects of History of Islamic Culture, can increase student motivation and learning outcomes. The complete achievements of student learning outcomes from pre-cycle to the second cycle can be seen in the table below:

Table 1. Pre-Cycle Learning Outcomes, Cycle 1, and Cycle 2

\begin{tabular}{clcccc}
\hline No & Name & Gender & \multicolumn{3}{c}{ Score } \\
\cline { 3 - 6 } & & & Pre - & Cycle & Cycle \\
& & & Cycle & $\mathbf{1}$ & $\mathbf{2}$ \\
\hline \hline 1 & Achmad Edo Zakaria & L & 55 & 75 & 85 \\
\hline 2 & Achmad Yusuf Arya Kusuma & L & 60 & 80 & 90 \\
\hline 3 & Adilla Dwi Maharani & P & 55 & 74 & 85 \\
\hline
\end{tabular}


Vol. 6 No. 2 December 2020

\begin{tabular}{|c|c|c|c|c|c|}
\hline \multirow[t]{2}{*}{ No } & \multirow[t]{2}{*}{ Name } & \multirow[t]{2}{*}{ Gender } & \multicolumn{3}{|c|}{ Score } \\
\hline & & & $\begin{array}{l}\text { Pre - } \\
\text { Cycle }\end{array}$ & $\begin{array}{c}\text { Cycle } \\
1\end{array}$ & $\begin{array}{c}\text { Cycle } \\
2\end{array}$ \\
\hline 4 & Adinda Marisa Maulida & $\mathrm{P}$ & 60 & 85 & 85 \\
\hline 5 & Ahmad Fahmil Makarim & $\mathrm{L}$ & 50 & 70 & 75 \\
\hline 6 & Ahmad Sulton Alim Mabrur & $\mathrm{L}$ & 78 & 90 & 95 \\
\hline 7 & Aisyah Salsabilla Fidela & $\mathrm{P}$ & 55 & 75 & 80 \\
\hline 8 & Aldi Muhammad Virzha & $\mathrm{L}$ & 70 & 80 & 85 \\
\hline 9 & Ali Usman Thalib & $\mathrm{L}$ & 50 & 60 & 85 \\
\hline 10 & Andhisa Febriantika & $\mathrm{P}$ & 76 & 85 & 95 \\
\hline 11 & Andre Prayoga & $\mathrm{L}$ & 50 & 60 & 70 \\
\hline 12 & Aprilia Sintia Para Dewi & $\mathrm{P}$ & 67 & 78 & 80 \\
\hline 13 & Aulia Indra Ramadhani & $\mathrm{P}$ & 78 & 80 & 85 \\
\hline 14 & Ayu Wulandary & $\mathrm{P}$ & 66 & 90 & 85 \\
\hline 15 & Danang Dwiky Ramadhan & $\mathrm{L}$ & 80 & 90 & 90 \\
\hline 16 & Dewi Nur Maulida & $\mathrm{P}$ & 56 & 70 & 95 \\
\hline 17 & Edo Prihatmoko & $\mathrm{L}$ & 70 & 75 & 75 \\
\hline 18 & Eka Rosyidatul Ulya & $\mathrm{P}$ & 65 & 70 & 75 \\
\hline 19 & Ellysa Maulidyaningrum & $\mathrm{P}$ & 80 & 85 & 90 \\
\hline 20 & Elma Lailatul Faizah & $\mathrm{P}$ & 70 & 78 & 78 \\
\hline 21 & Erfida Maharani & $\mathrm{P}$ & 66 & 75 & 78 \\
\hline 22 & Faisal Riza Rahman & $\mathrm{L}$ & 40 & 60 & 74 \\
\hline 23 & Farid Agus Afandi & $\mathrm{L}$ & 75 & 75 & 79 \\
\hline 24 & Febi Alfina Nadia Putri & $\mathrm{P}$ & 60 & 66 & 90 \\
\hline 25 & Frenha Rama Harya Vilanta & $\mathrm{L}$ & 58 & 60 & 74 \\
\hline 26 & Gita Tri Wulandari & $\mathrm{P}$ & 67 & 75 & 80 \\
\hline 27 & Nadira Salsabila & $\mathrm{P}$ & 65 & 85 & 90 \\
\hline 28 & Noor Adzni Azzahra Fitriyani & $\mathrm{P}$ & 72 & 89 & 95 \\
\hline
\end{tabular}




\begin{tabular}{|c|c|c|c|c|c|}
\hline \multirow[t]{2}{*}{ No } & \multirow[t]{2}{*}{ Name } & \multirow[t]{2}{*}{ Gender } & \multicolumn{3}{|c|}{ Score } \\
\hline & & & $\begin{array}{l}\text { Pre - } \\
\text { Cycle }\end{array}$ & $\begin{array}{c}\text { Cycle } \\
1\end{array}$ & $\begin{array}{c}\text { Cycle } \\
2\end{array}$ \\
\hline 29 & Sesil Adelia Wijaya & $\mathrm{P}$ & 66 & 79 & 80 \\
\hline 30 & Vahra Devinta Arifianti & $\mathrm{P}$ & 75 & 80 & 98 \\
\hline 31 & Vina Amelia & $\mathrm{P}$ & 75 & 75 & 80 \\
\hline 32 & Wafiq Aqul Azizah & $\mathrm{P}$ & 55 & 60 & 72 \\
\hline 33 & yuliana febrianti & $\mathrm{P}$ & 70 & 80 & 88 \\
\hline 34 & Yumnaa Kamilah Rachmadie & $\mathrm{P}$ & 65 & 85 & 95 \\
\hline & Total & & 2.200 & 2.594 & 2.856 \\
\hline & Average & & 65 & 76 & 84 \\
\hline
\end{tabular}

Table 2. Recapitulation of Test Results

\begin{tabular}{cccc}
\hline \hline Post Test Results & Pre-Cycle & Cycle 1 & Cycle 2 \\
\hline \hline The Highest Score & 80 & 90 & 98 \\
\hline Lowest Score & 40 & 60 & 70 \\
\hline Average & 65 & 76 & 84 \\
\hline Percentage of Completeness & $23 \%$ & $71 \%$ & $88 \%$ \\
\hline
\end{tabular}

\section{CONCLUSION}

Several previous studies using the same method have not shown an increase in Several previous studies using the same method have not shown an increase in learning motivation and learning outcomes simultaneously in the subject of History of Islamic Culture. Fakhrurrazi's research was carried out on the subject of Al Qur'an and Hadith with the conclusion that the sort card method was able to increase motivation and learning ability. Hasanah and Wahyuni's research using the same method was carried out in the subject of Akidah Akhlak. Meanwhile, the research conducted by Husnul and his friends was carried out in mathematics.

Based on classroom action research that I have done using the sort card method, it can be concluded that the sort card method can increase student 


\section{Fitrah \\ $\triangle$ Jurnal Kajian Ilmu-ilmu Keislaman}

Vol. 6 No. 2 December 2020

motivation in the learning process in the subject of History of Islamic Culture. This is evidenced by the increase in student participation during the learning process. All students are able to follow learning in a focused way and actively participate in the learning process. It is also able to improve student learning outcomes. This is evidenced by the increasing percentage of mastery learning obtained by students in the first and second cycles. The sort card method is able to increase motivation and student learning outcomes simultaneously in the subject of History of Islamic Culture.. 


\section{REFERENCES}

Al Attas, S. M. N. (1979). Aim and Objectives of Islam Education. King Abdul Aziz University.

Al Harafi, S. M. (2016). Buku Pintar Sejarah E Peradaban Islam. Pustaka Al Kautsar.

Amrulloh, M. A., \& Puspita, R. (2019). Qawa'id wa Tarjamah Method and Card Sort Strategy in Shorof Learning in Madinah Modern Boarding School. International Journal of Arabic Language Teaching, 1(01), 1-13.

Arikunto, S. (2006). Prosedur Penelitian Suatu Pendekatan Praktek. Rineka Cipta.

Conrad, L. Y., Demasson, A., Gorichanaz, T., \& VanScoy, A. (2019). Exploring card sort methods: Interaction and implementation for research, education, and practice. Proceedings of the Association for Information Science and Technology, 56(1), 525-528. https://doi.org/10.1002/pra2.81

Fakhrurrazi. (2016). Penerapan Metode Card Sort Dalam Peningkatan Motivasi Dan Kemampuan Belajar Siswa Bidang Studi Al-Qur'an Hadits Pada Siswa MTs Darul Huda Kota Langsa. Jurnal Al Ikhtibar, 3(2), 87-101.

Fauziyah, N. (2013). Faktor Penyebab Kejenuhan Belajar Sejarah Kebudayaan Islam (SKI) Pada Siswa Kelas XI Jurusan Keagamaan di MAN Tempel Sleman. Jurnal Pendidikan Agama Islam, X(1), 106.

Giraudeau, P., Olry, A., Roo, J. S., Fleck, S., Bertolo, D., Vivian, R., \& Hachet, M. (2019). CARDS: A Mixed-Reality System for Collaborative Learning at School. Proceedings of the 2019 ACM International Conference on Interactive Surfaces and Spaces, 55-64. https://doi.org/10.1145/3343055.3359721

Hamalik, O. (2007). Psikologi Belajar dan Mengajar. Sinar Baru Algesindo.

Hartono. (2008). PAIKEM (Pembelajaran Aktif, Inovatif, Kreatif, Efektif dan Menyenangkan). Zanafa.

Hasanah, U., \& Wahyuni, S. (2019). Implementasi Model Pembelajaran Card Sort Pada Mata Pelajaran Akidah Akhlak Kelas IV MI Al-Islam Desa Pranggang Kecamatan Plosoklaten Kabupaten Kediri. Jurnal Intelektual, 9(April).

Husnul, S., Risan, \& Andinny, Y. (2018). Peningkatkan Hasil Belajar Matematika Siswa Sekolah Dasar Melalui Penerapan Pembelajaran Aktif Metode Card Short. JPD: Jurnal Pendidikan Dasar, 9(2), 21-29. https://doi.org/10.21009/JPD.091.03 


\section{Fitrah}

$\Rightarrow$ Jurnal Kajian Ilmu-ilmu Keislaman

Vol. 6 No. 2 December 2020

Lahmar, F. (2020). Islamic Education: An Islamic "Wisdom-Based Cultural Environment" in a Western Context. Religions, 11(8), 409. https://doi.org/10.3390/rel11080409

Mahmud, S., \& Idham, M. (2017). Strategi Belajar Mengajar. Syiah Kuala University Press.

Manshur, F. (2020). Typical Literary Works of Pesantren on Righteousness Teaching within Cultural Transformation. Journal of Social Studies Education Research, 11(4), 114-148.

Mashudi, M. (2020). Pesantren-Based Higher Education Institutions: The Format of Modern Islamic Education. Ta'dib: Jurnal Pendidikan Islam, 25(2), 119135. https://doi.org/10.19109/tjie.v25i2.6826

Mulyasa, E. (2011). Praktik Penelitian Tindakan Kelas. Remaja Rosdakarya.

Petrie, H., Power, C., Cairns, P., \& Seneler, C. (2011). Using Card Sorts for Understanding Website Information Architectures: Technological, Methodological and Cultural Issues. In P. Campos, N. Graham, J. Jorge, N. Nunes, P. Palanque, \& M. Winckler (Eds.), Human-Computer Interaction - INTERACT 2011 (pp. 309-322). Springer. https://doi.org/10.1007/978-3642-23768-3_26

Rahman, F. (1984). Islam and Modernity: Transformation of an Intelectual Tradition. The University of Chicago Press.

Saif, L. (2020). "That I Did Love the Moor to Live with Him": Islam in/and the Study of "Western Esotericism." In New Approaches to the Study of Esotericism (pp. 67-87). Brill. https://doi.org/10.1163/9789004446458_005

Sakdiyah, S., \& Sari, Y. (2016). Penerapan Model Pembelajaran Card Sort Untuk Meningkatkan Keaktifan Siswa Kelas V Se-Gugus Kebonsari Kecamatan Sukun Kota Malang. Jurnal Pendidikan - Teori, Penelitian, Dan Pengembangan, 1(10), 2004-2009. https://doi.org/10.17977/jp.v1i10.7414

Suparlan. (2006). Guru Sebagai Profesi. Hikayat Publishing.

Suyadi. (2011). Panduan Penelitian Tindakan Kelas. Diva Press.

Zaini, H. (2008). Strategi Pembelajaran Aktif. Pustaka Insan Madani.

Zuhairini. (1986). Sejarah Pendidikan Islam. Direktorat Jenderal Pembinaan Kelembagaan Agama Islam. 